\title{
Contesting the Social Spaces: Gender Relations of Literary Communities in Yogyakarta and Surakarta
}

\author{
Wening Udasmoro dan Saeful Anwar \\ Faculty of Cultural Sciences, Universitas Gadjah Mada
}

Received: 2019-05-18 Accepted: 2019-11-17

\section{Keywords: \\ Space, \\ Literature, \\ Communities, \\ Gender, GIS}

Correspondent Email: udasmoro@ugm.ac.id

\begin{abstract}
This research seeks to map the gender relations within literary communities and their contestations in gaining social and financial capital in Yogyakarta and Surakarta social spaces. The presence of literary communities in these spaces, on the one hand, explains the local and specific self-identities of the communities, as well as their heterogeneity in gender relations. In particular, this research maps these communities' differences in expressions, trajectories (visions for the future), themes, narrations, language, and networks based on their gender relations. The Geographic Information System (GIS) method is used to map and explore the gender issues in these literary communities. By understanding the mapping of these literary communities, the dynamics of the social spaces used by these communities can be traced synchronically within a specific period. It can also be followed up when the database is used diachronically over time. This research finds that social spaces that enable open narration are insufficient to ensure the equality of women and men. Flexible domestic spaces for women are also necessary to ensure women to be active in creating the trajectory of the literary communities since they have capacities to do it.
\end{abstract}

(C) 2019 by the authors. This article is an open access article distributed under the terms and conditions of the Creative Commons Attribution(CC BY NC) licensehttps://creativecommons.org/licenses/by-nc/4.0

\section{Introduction}

This research seeks to map the use of the social spaces of Yogyakarta and Surakarta by literary communities and their different constructions of male and female identities using the Geographic Information System (GIS) method. The concept of social space was first introduced by Emile Durkheim (1893), who explained that social space is the space in which human groups exist (Shimazu, 1995). This concept was further developed by Durkheim's successors, such as Marcel Mauss in his book Double Morphology of Eskimo Society (Claval, 1984), and again used by other thinkers such as Condominas (Condominas, 1980) and Henry Lefebvre (Lefebvre, 1974). These one later thinkers saw space as being used both by individuals and collectives, and can be used to explain entities through their cultural production and representation (Lefebvre, 1974)1974). Lefebvre is one of the most important French scholars who contributed to the foundation of critical theories of human communication. Related to the theory of space, he argued that the production of space follows the production of language and code. He further argued that a theory of space should be a unitary theory that explains comprehensively the field of physical, the mental and the social. Social space may also be used to assert a community's identity
(Udasmoro, 2014), to express itself and its social goals, and to create networks between group members. Social space enables groups, such as literary groups, to 'create' identities and agendas that reflect their trajectories (Giddens, 1991; Valenta, 2010) or future vision and mission. According to Giddens, in a post-traditional order, self-identity is reflexive. It is not a quality of a moment but an account of a person's life. According to Giddens, personal identity is not found in behavior or the reaction of others but in the capacity to keep a particular narrative going (Giddens, 1991: 54). There must be a continually integrates events which occur in the external world to create an ongoing story about the self. This research on literary communities reflects how the production of space that use language as a way to narrate the external worlds is combined with the idea of the ongoing construction of the self though the dayto-day ongoing story in integrated events.

To date, the discussion of literature has concentrated on the literary text itself, such as by interpreting the literary text and giving meaning to its narrative content (Udasmoro, 2017). The formalist and the structuralist approaches have been dominating the literary analysis, especially about giving meaning to the literary texts. No sociological research has explained how social spaces within specific geographical spaces 
are used for contestation by different subjects, such as the author or the literary communities' leaders in literature. Some researchers have attempted to connect literature with the sociological and ethnological situation, such as by connecting the literary work with social discourses, such as through interviews with readers. This is intended to recognize readers' views of the literary works being read (Udasmoro, 2018). Such an approach examines the literary text using an ethnographic approach, looking at the work based on the social experience(s) and culture(s) of its readers.

Other research has examined the cultural production of literary texts by examining the writer within the context of a specific cultural space. Research using such an approach has, for example, identified the contestations of writers in open literary spaces (Indrianto, 2016; Mahmud, 2015; Salam, 2014). This has shown in Yogyakarta, for example, that writers have attempted to assert themselves and compete with other writers (Anwar, 2013; Nugraha, 2015; Salam, 2013). Although researchers have attempted to connect literary texts with the sociological and anthropological situation of individuals within specific geographic situations, the use of the social space within the geographical context has not been examined, particularly in Indonesia (or, in the context of this research, Yogyakarta, and Surakarta). These two neighboring cities lie in two different provinces, Daerah Istimewa Yogyakarta (Special Region of Yogyakarta) and the province of Central Java. However, these cities have several aspects in common. The similarities are related to their situation as cultural cities where different groups of cultural activities are established. They are also considered as the center of arts and literature in Java. Literary communities and their activities have yet to draw much attention from researchers, even though these literary communities are among the ones creating the texts. The texts produced are geographic, as the activities of literary communities within specific geographic contexts are complementary and mutually provide input while simultaneously competing to achieve economic goals and accumulate social capital (Bourdieu, 1991) (i.e., through networking, consecration of works/writers.). Social space is simultaneously synchronic (within a specific time frame, such as five years) and diachronic (periodical), meaning that every period will reflect the literary ideology it follows (Udasmoro, 2017).

To date, no research in the context of Indonesia has mapped how literary communities have constructed themselves within specific geographical and social spaces. Geographical regions, particularly those known for their education and home to thousands of students, are often home to several literary and arts communities, the examination of which is essential as they have contributed significantly to Indonesian literature. Prominent literary communities have emerged, for example, in the Special Administrative Region of
Yogyakarta (DIY, or simply Yogyakarta) and Surakarta, and attempted to promote literature and literariness. To locate more specifically, these two regions below is the position of Yogyakarta dan Surakarta in the map of Java.

Yogyakarta and Surakarta, as cultural icons and student cities, are used as social spaces by literary communities to ensure the perpetuation of the communities and of literature itself, as well as social spaces for the creation of literature. In the years during the New Order era, especially after the 1990s, the literary realm was marked by the presence of theatrical groups known throughout the Indonesian archipelago. These included, for example, the Gandrik Theater in Yogyakarta (Sahid, 2012), which used its performances to provide social criticism to the government. However, after the fall of the New Order regime, a different approach to literature was undertaken, as communities felt that the time to challenge the government was over. In this era of reform (1998 to present), literary communities became new arenas for the use of creative space in Yogyakarta and Surakarta.

Various literary communities emerged in Yogyakarta and Surakarta using a variety of means. Interestingly, all of these communities have their agendas for exploring and exhibiting their own identities through their members. The discussions held by these communities are used not to discuss the works of a national literature that have become widely known among the public but instead attempted to present the literary narratives of their members. These literary communities were, for the most part, established following the fall of Suharto in 1998, when freedom of expression received increased attention and protection. These communities emerged over time and developed dynamically. Over time, some overgrew, while others collapsed owing to internal and external issues. Despite this diversity, the literary communities in Yogyakarta and Surakarta share a tendency to use the social space of their boundaries to assert their existence and struggle for their trajectories.

Although these communities are working collectively for their groups' trajectories, however, the expression of their identities is gendered. The construction of social spaces shows the domination of male representation (Staeheli \& P.M., 2000). The literary communities are shaped in the geographical spaces and thus can be viewed as experiencing power relations in their social practice. Although they may share a similar trajectory, seeking to assert and present their identities, these communities are not homogenous, neither internally nor to other communities; this includes in their gender relations, as the communities consist of both men and women. This gendering is found in various forms. First, there are differences in how male and female community members express their identities, 


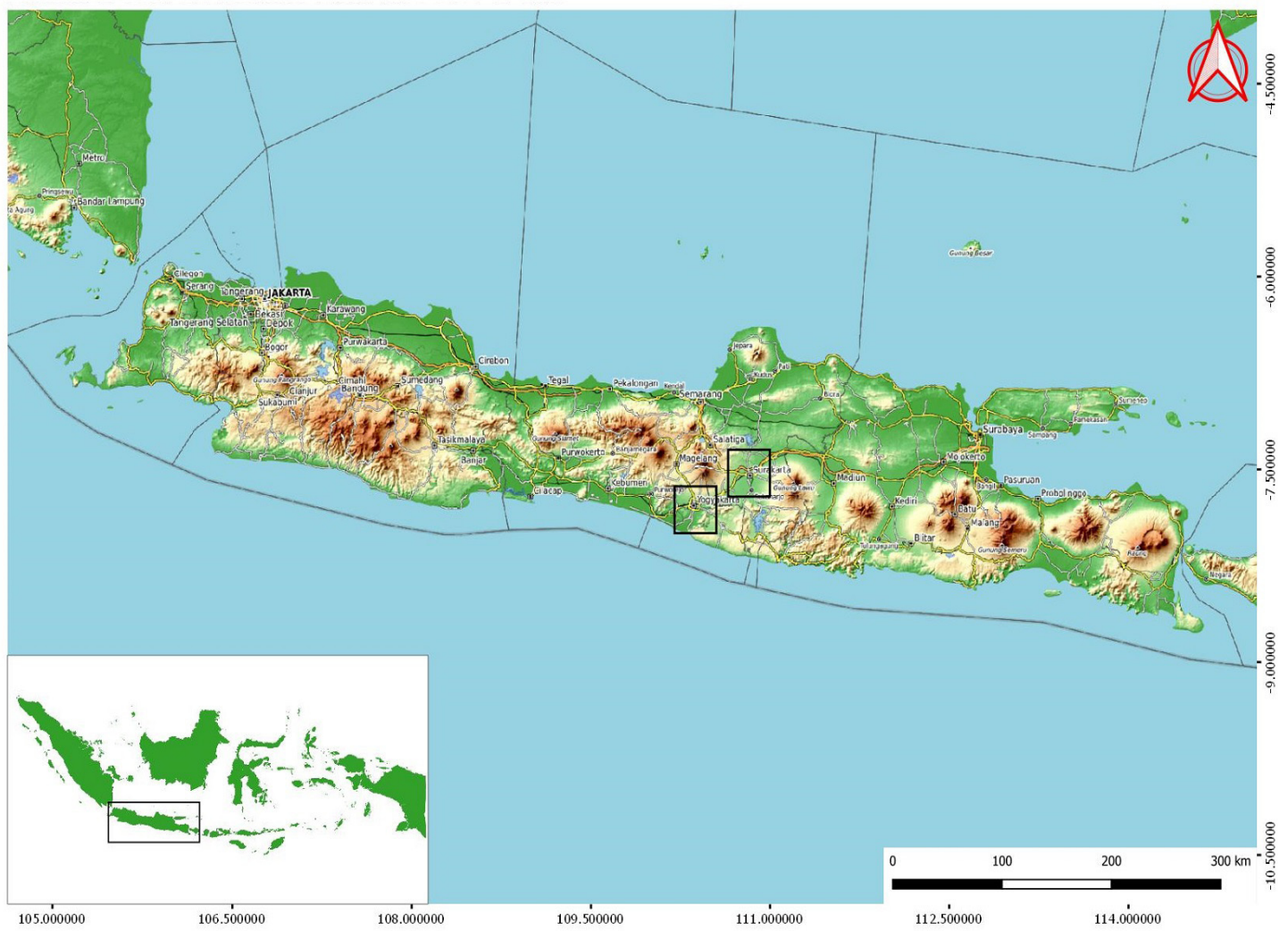

Figure 1. The position of Yogyakarta and Surakarta in the Map of Java

including how they envision the future (i.e. trajectory) of their community. Second, there are differences in the expressions and writings of male and female community members, including the language they use and the themes they select. Third, recognizing that these literary community members are outside groups within the national literary framework, there are differences in the means through which men and women negotiate and express their situation relative to the larger and hegemonic national literature community.

This research attempts to explore and understand how do these communities contesting themselves by using the spaces of Yogyakarta and Surakarta? What are the different trajectories/visions for the future that distinguish male community members from female community members? What literary themes and contents distinguish male and female community members? How can gender relations within literary communities in Yogyakarta and Surakarta be mapped? It is envisaged that geographical mapping will enable a coherent interpretation of gender relations in these two communities.

The world is topology or a social space (Bourdieu, 1977, 1984, 1990). There are arenas of contestation (champs de force) that are connecting each other. The social space is connected by the arenas, where people are struggling to accumulate the capitals (Bourdieu, 1990). The social space has three essential dimensions: social capital, composition of social capital, and trajectory (overtime) (Munk, 2003: 2; Pierre Bourdieu, 1984, 1990). Bourdieu understood trajectory as a strategy of reconversions, in which agents (people) convert capital to other forms of capital over time and ultimately accumulate social capital. In La Distinction book, social capital has a central role in the construction of individual and social groups' trajectories (Bourdieu, 1984).

A group's social capital is essential, as the more forms of social capital accumulated, the higher the chance this social capital can be converted to other forms of capital. Meanwhile, social capital is composed of various forms of capital, including cultural capital (for instance, language, different skills), abd symbolic capital (for instance, status, pride). The amount of capital accumulated will contribute to the achievements and trajectories of individuals and groups in a social space. Exploring social space requires the exploration of social traces, as it is from these social traces that individuals and groups' reconversions of capital can be identified. The positions of individuals and groups within the social space, as well as their capital, is not only linked to their incomes and educations, but also their genders, social classes, and ethnicities.

Literary communities, as groups of individuals, also consist of three components (Bourdieu, 1991). They include members from various social backgrounds, including different gender, educational, and economic experiences, and thus accumulate social capital 
differently. Diversity in membership is also assumed to explain the dynamics of the community's trajectory.

In the context of gender and geography, there has been a view that spaces become increasingly complicated when discussing the spaces of men and women. The feminist geographer, in the article entitled article "Mapping the Margins: Intersectionality, Identity Politics, and Violence Against Women of Color" (published in Stanford Law Review in 1991) explained this complexity of space, a gendering of the public and the private space (Crenshaw, 1994). It is inspired by The Feminine Mystique book (Friedan, 1963). She also recognized that both urban and rural spaces experienced understood differently by men and women. There are situations, such as in conflict areas, where rural spaces may become occupied by women because men have migrated to the city. In their article entitled Spaces for Feminism in Geography, other scholars argue that the social spaces are constructed by masculine domination (Staeheli \& P.M., 2000: 143). They take the stance that there should be mutual construction of place and gender.

These diverse spatial and geographic contexts give rise to various assumptions regarding the context of literary communities. For example, why are women more prominent in urban literary communities than in rural ones? The intersections of gender categories and other social categories, including ethnicity (Mohanty, 1984), are among the points discussed herein, as questions of education (for example) may be determinant factors.

\section{The Methods}

This research uses a GIS approach to spatial analysis, a way of working that seeks to analyze an unlimited amount of spatial data (Brimicombe, 2010; Maguire, 2008) or requires a depth of information regarding specific spatial phenomena. Data are collected, analyzed, and then presented as spatial information or as maps. This method is used to map the relationships and connections between different entities within specific geographical spaces, using spatial data and specific attributes (Yuwono, U.N. Winardi, \& Saktimulya, 2017). The entities in this article are those literary communities that have emerged in Yogyakarta and Surakarta. The locations of these communities are the spatial data that will be mapped. Meanwhile, specific attributes will indicate the variables influencing each entity. Two main variables are used as the basis of the current research, the first being social space and the second being the gendered trajectory.

Six essential components influence the variable of social space: identity, works written, number of community members, inter-subject relations, community dynamics, and spatial aspects (i.e., Yogyakarta and Surakarta). Meanwhile, there are ten components to gendered trajectory: relative number of men and women, thematic comparisons, number of presentations, diversity in narratives, intersections with other social categories (i.e. social class, age, and ethnicity), different community trajectories, different gendered communities, different themes discussed, different issues addressed, different self-identities, and different languages used.

Subsequent stages include the formulation of conceptual design (regarding the data collected), operational design (preparation of basic mapping), and cartographic design (preparation of maps). The formulation of research questions is intended to ensure congruence between map design and literary design. Interviews were conducted in both spaces (Yogyakarta and Surakarta). In total, members from ten communities were interviewed. Although Yogyakarta is known as having more literary communities than Surakarta, the communities can be distinguished not only quantitatively, but also qualitatively.

\section{Results and Discussion}

\section{Literary Communities and the Contestation in Social Spaces}

The literary communities in Yogyakarta and Surakarta are products of the reform era in 1998. All of the ten communities examined in this research were established after the year 2000. Most of them were established in the first decade of Indonesia's political reform; six communities were founded before 2011. Only one community was established after 2015, namely in 2017. These literary communities represent a new generation of literature in Yogyakarta and Surakarta. They are dominated by youths, particularly young men, most of whom are university students or alumni. These communities are highly heterogeneous in terms of ethnicity and the university of origin.

Sociologically, these literary communities can explain the new perspectives that have emerged in the social spaces of Yogyakarta and Surakarta as freedom of speech and expression was granted following the fall of the New Order in 1998 (O'Rourke, 2002). This regime, headed by President Suharto, formally held power for thirty years (1968-1998) and created a situation in which Indonesian literature was strictly censored but also resisted the regime in power (Rizki, 2014). It was in the literary realm that the earliest freedom of expression activists emerged. The emergence of new literary communities in the early 2000s was the fruit of this struggle against authoritarianism and its sometimes-violent oppression of literature. For example, several writers experienced physical violence, detention, or even the banning of their works. These new literary communities, meanwhile, emerged within social spaces that were wide open. The widest of these were in Yogyakarta and Surakarta, where university students had actively demonstrated against the previous authoritarian regime. 
Why was literature used as an arena for contestation in the New Order? Under the regime's authoritarianism, open resistance was seen as too complicated, and thus literature was considered the most appropriate venue for the opposition. It offered activists a means for challenging Indonesia's leadership in the face of Indonesia's stifling government policies, as journalism-often seen as strategic means for explicitly challenging authoritarian practices-was toothless. Out of this spirit of resistance, there emerged a passion for establishing new literary communities.

The following map below shows the literary communities and their distribution. In Yogyakarta, communities are primarily centered in Yogyakarta City, Sleman, and Bantul; in Wonosari and Kulonprogo, meanwhile, literary communities are not active. This can be explained by Yogyakarta City, Sleman, and Bantul being near major university campuses; as such, these campuses are, to some extent, linked to the establishment of literary communities. Meanwhile, the literary communities in Surakarta are centered primarily in Surakarta City, Karanganyar, and Kartosuro; again, there is a link between universities and the emergence of literary communities.

Students and alumni established these literary communities for various reasons. Almost all communities mentioned that these communities were intended to improve their member's ability to write literature. As such, the communities were often established to guide members in their writing of poetry, essays, and prose.

The mapping of literary communities indicates that communities in both Yogyakarta and Surakarta generally have male and female members. Most group members, however, are male, with female members being a minority in both Yogyakarta and Surakarta; one community is homogenous, with only male members. This occurred not because they specifically sought out men, but because they had difficulty getting female members. This may be attributed to the difficulties experienced by male and female members when communicating; female community members often uncomfortable as they view the male members as being vulgar in their communications. For example, male community members often use sexist jokes, unnerving female community members. In this context, women members feel uncomfortable because they are placed as sexual objects (Mulvey, 1975). Furthermore, female members must overcome numerous obstacles to remain active in their communities, especially after marriage; they may, for example, be expected to move to another city or be expected to stay within the domestic space (Friedan, 1963).

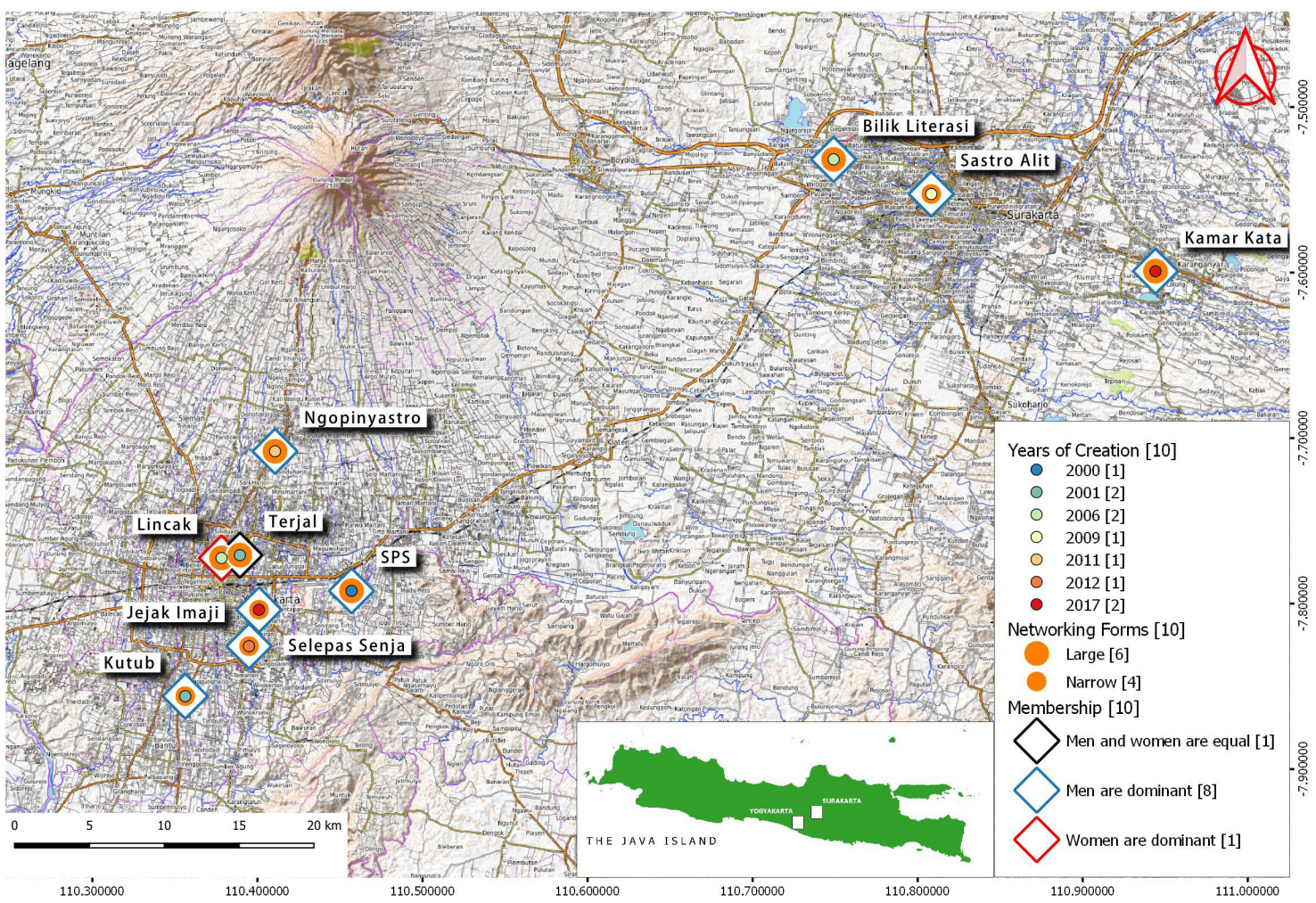

Figure 2. Map of Membership, Years of Creation and Networking 
The networks of these communities can be categorized based on their breadth. Broad networks, for example, may be indicated by communities having professional contacts with more than one other community, or by working with communities involved in other fields (such as visual arts). Meanwhile, 'narrow' networks may exist only between different communities. These networks may be quite strong, with numerous collaborative endeavors between specific groups, such as Jejak Imaji and Kutub. Other such 'narrow' networks may exist when individuals are part of more than one literary community. For example, some members of Bilik Literasi are also members of Sastro Alit in Surakarta and only feel that their communities are in competition during writing contests. This occurs primarily when communities have a shared vision, such as using writing to accumulate financial capital by winning writing competitions.

\section{The Gendered Production of Works}

Comparing the number of male and female members of the literary communities surveyed, five communities have mostly male membership, while two communities have mostly female membership. Meanwhile, one community consists entirely of men, while two communities have an equal number of male and female members. In a gender context, this composition, where men tend to be more numerous than women in literary communities, indicates the dominance of male narratives in literary communities. Men are the ones who explore themselves and their identities through the literary communities, who express themselves as subjects (Tuchman, 1978) capable of mobilizing and shaping Indonesian literature.

Meanwhile, the relatively small number of female community members indicates that their narratives are less represented in the realm of literature. Literary communities, the vanguard of new writers' attempts to find a space within the constellation of Indonesian literature or to gain recognition at the national level, ultimately become social spaces for men. These literary social spaces are created by groups of men and used to promote the interests of men. Below is the map of the position between men and women in the communities.

From the above map, regarding the positions of women, five communities show no shared tendencies in women's literary works and creative processes. These women may sometimes write works of literature, and sometimes they may not; this distinguishes them from the men, who are more active in writing. Of the ten communities, two have no female members who have produced works of literature. These women members are only supporting their community and have no intention to produce literary works. Women are present, but they do not have full narration expressed in the communities (Friedan, 1963; Tuchman, 1978). Meanwhile, two communities have female members who have produced literary works, and those works have female members who have produced literary works that deal with their ostracism and isolation within the male-dominated literary sphere.

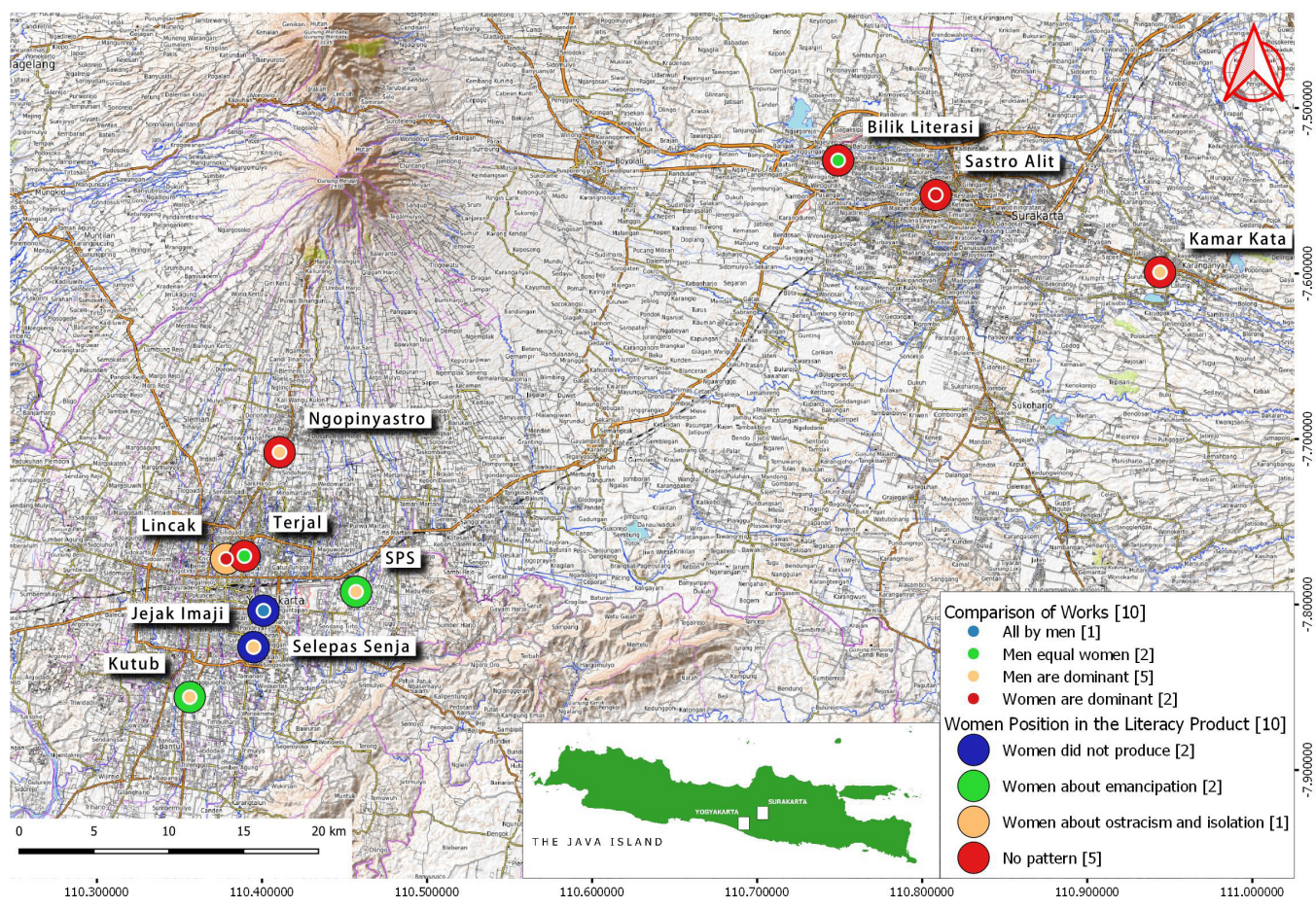

Figure 3. Works and the role of women spatial pattern 
It is also historical in nature, with its roots in the establishment of the various literary communities. After female members married and moved to other cities, it became impractical for them to participate in these literary communities. Several communities have attempted to position men and women equally, particularly in the contents of their literary works. However, most of the writers in these communities have continued to position women as objects in their works. They are positioned as suffering, and as occupying a lower position than men. Meanwhile, two communities have been able to position women as subjects in their narratives.

\section{The Gendered Trajectories of Literary Communities}

Most of the literary communities in Yogyakarta and Surakarta follow the general trajectory of joining writing competitions. This is intended, in part, to increase these communities' financial capacities by using their social capital (Bourdieu, 1977) as the ones who can create the literary works. Many of the literary awards in Indonesia, both at the local and national level, include financial prizes. By winning writing competitions, they gain the opportunity to access financial capital for their interests and their communities' interests. Aside from competitions, these communities also attempt to gain access to the media (newspapers/magazines). This, too, has the ultimate goal of gaining access to financial capital. A third trajectory is gaining access to public spaces, such as by reading poems, reading short stories, and conducting other literary activities for selfrepresentation. Access to public spaces is important for these literary communities because it allows them to gain prestige and broader public recognition. Below is the map of that situation.

Meanwhile, aside from these general trajectories, literary communities also have their community trajectories. These trajectories are specific to individual literary community. Two communities, for example, tend to use their activities for creative purposes, such as winning competitions by writing poems and short stories.

Meanwhile, one community's trajectory is primarily identified with entertainment, as they consider literature a means of entertaining themselves and others (such as children). Furthermore, communities may use literature to increase their knowledge. The reflective thoughts in literature are used to expand their understandings of sociological, cultural, and political problems.

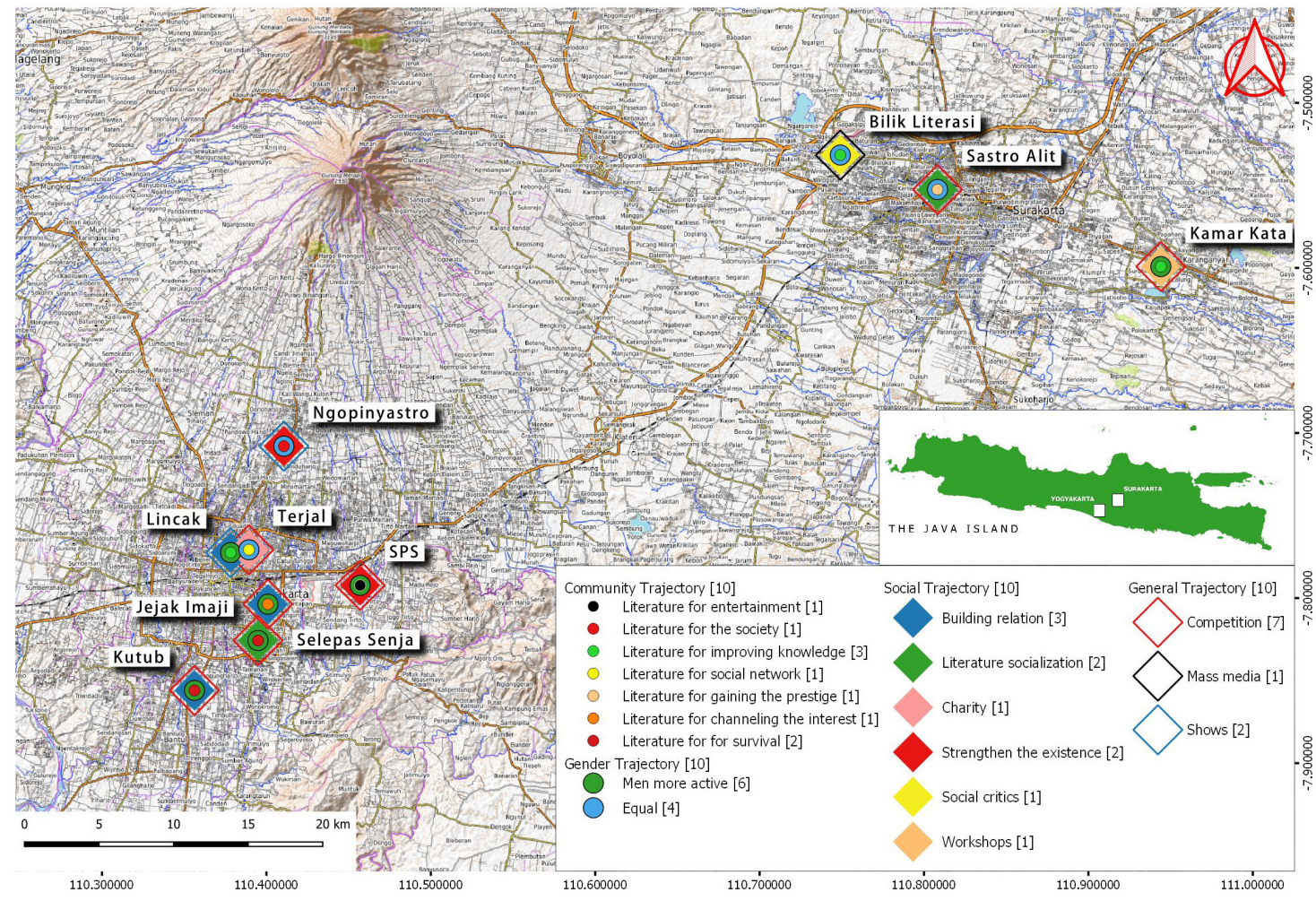

Figure 4. Trajectories patterns 
In their gendered trajectories, the male members of most communities are more active than women, both in their writing and in their administrative activities. Male community members use the social spaces of their literary communities maximally, as the social space is more open for them than for women. The opening of space to them is linked to the structures of their societies, particularly the continuous social and cultural reproduction and distinction of private and public spaces. In Indonesia, perhaps the clearest example is the fact that women actors emerged in the national theatre later than male actors, a situation that occurred historically because they were not allowed in the public space at night (unlike men, who had that freedom). Such a situation has remained until today, including in literary communities in Yogyakarta and Surakarta. Women have less access to public spaces, and thus cannot maximally access the social spaces of their communities (Houle, 2000). As a consequence, the trajectories of these literary communities are determined by men, and thus the social spaces of literary communities are used to express male ideologies and interests.

\section{Gender and the Elaboration of Issues}

Regarding the issues discussed in their literary products, most communities have never created a frame for the issues addressed by their works. The freedom of creation and expression that emerged following the fall of the New Order government was a significant factor in the literary communities' creation and expression. Communities became free to write about whatever topic or issue they desired. Only one of the communities surveyed exhibited a preference to address a particular topic, namely identity issues. Madurese and other marginal groups' identities have often been discussed by the works of these communities. The map below shows how the issues elaborated by the different literary communities.

The issue of minority identities is not addressed without reason. Members of this community hold that the limited narrative space given to minorities means that they require more space to narrate themselves. The social spaces of these communities are used to promote the interests of certain social categories, reflecting the argument that gender intersects with ethnicity, social class, and age group (Mohanty, 2003). In the context of the literary communities in Yogyakarta, Jejak Imaji (for example) tends to deal with ethnic and minority issues (such as the struggles of the lower class) in its works, with many of the writers in the community being men.

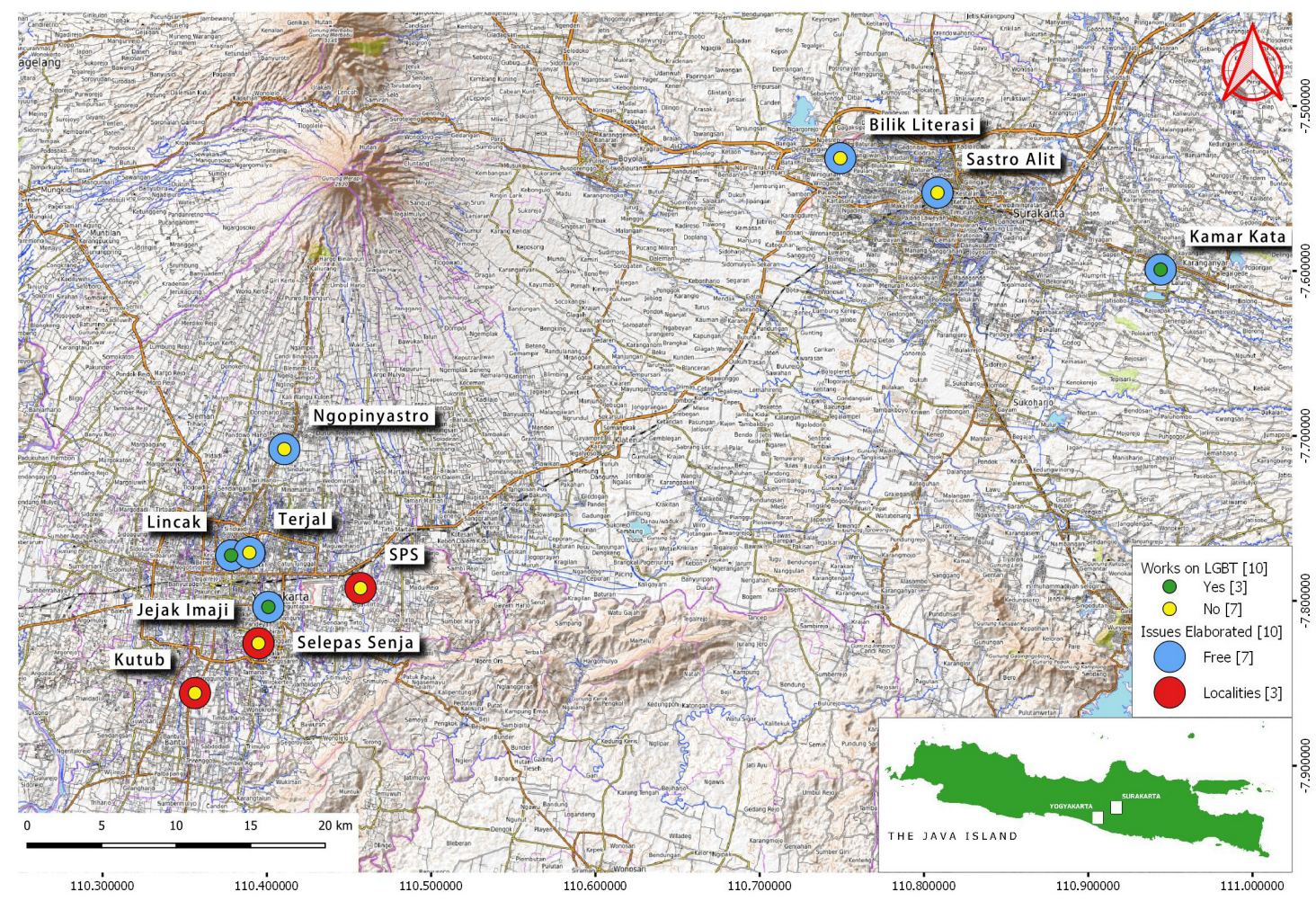

Figure 5. Map of issues elaborated and LGBT theme 
However, despite efforts to defend minority groups, none of the literary communities surveyed have attempted to address the most sensitive minority issues, such as the position of Lesbian, Gay, Bisexual, and Transgender (LGBT) individuals in Indonesia. Most communities expressed a lack of interest in addressing LGBT themes in members' literary works, and indeed only two groups explicitly stated that their members had written about this topic. LGBT themes are avoided by writers in these literary communities not only out of a lack of interest but also to avoid ideological conflicts with general society, particularly anti-LGBT groups.

\section{Gender and Narration in Literary Communities' Social Space}

In their use of social space, women are marginally positioned because they are less likely to narrate themselves (Agustina \& Udasmoro, 2018). The limited spaces available to women as subjects instead leads to literary narratives that position them as objects, often as objects being narrated by male writers. Interestingly, when male community members write, they frequently attempt to narrate female characters, while female community members tend to narrate themselves in their literary works. As such, the male writers go outside the boundaries of their own identities and attempt to explore and narrate women, while women tend to write about themselves.
In studies of gender and the use of narratives in social spaces (particularly public spaces), there is a continuously transforming dynamic. Pioneers of studies of women's narratives in public spaces noted that narratives had historically been dominated by men (Friedan, 1963; Tuchman, 1978). Women existed within male-written narratives, but were primarily the objects of men's narratives. They were narrated within public spaces not for their interests, but rather for the interests of the male writers and their male gaze (Mulvey, 1975), heterosexual men's search for visual satisfaction. The following map indicates the narration of women and the language style used.

From this map, it is evident that, when women community members write, their writings tend to deal with the topics of emancipation and isolation. In other communities, meanwhile, women have not produced literary works, and thus no tendency in their writings can be seen. However, this can be explained in another way. Although women are minorities in most literary communities, and thus have limited involvement in the social space, they use their limitations to express themselves as subjects. They narrate themselves and all of their limitations. Women having the ability to narrate themselves and establish counter-narratives is important, given the tendency for male writers to position women as objects. Nonetheless, some female writers in these literary communities continue to depict women as being isolated from the broader world, thereby reproducing the structures established by male writers.

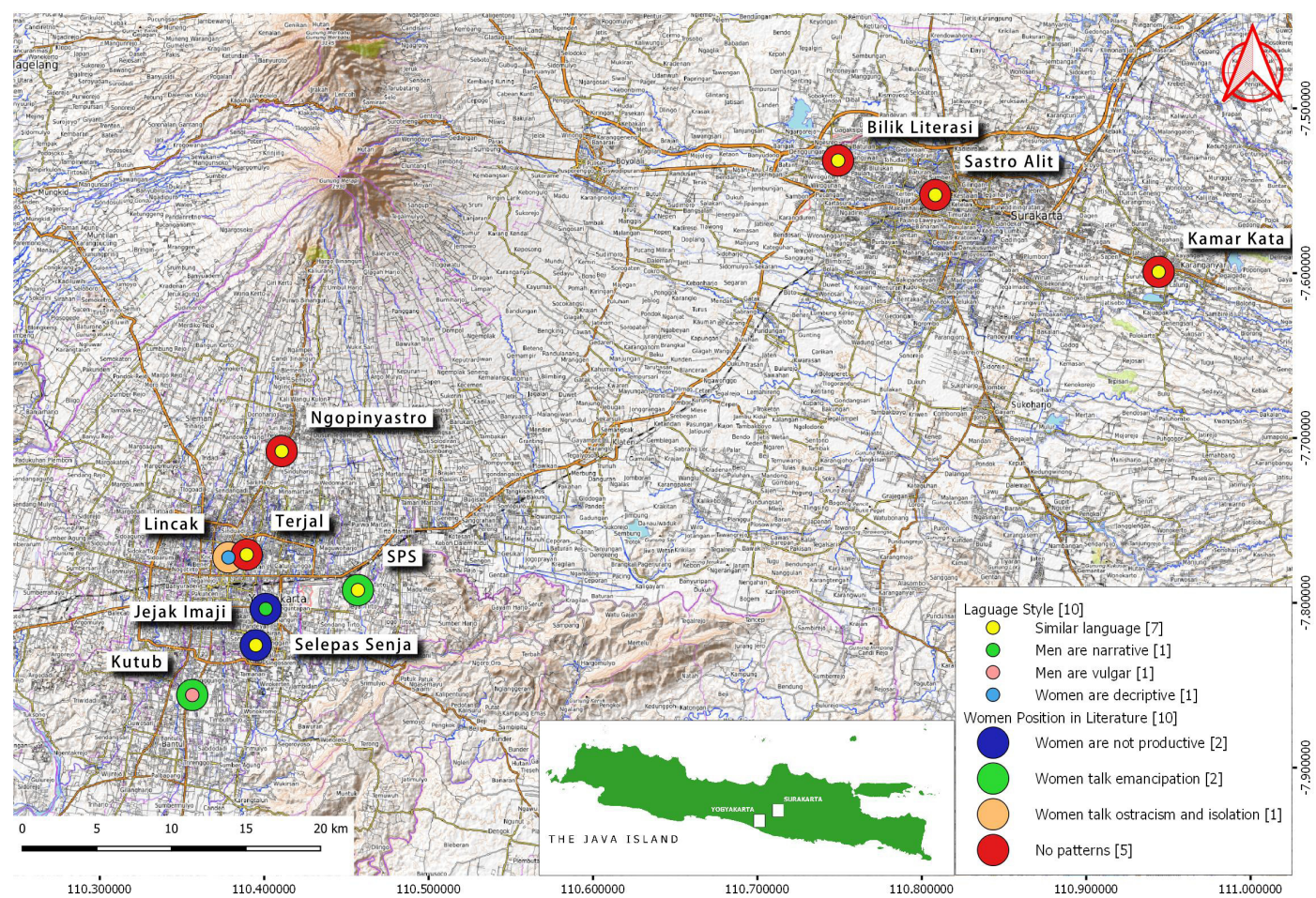

Figure 6. Map of women's literature and language style 
In their writing styles, female and male community members are also different. Male community members tend to have a more narrative style, while women members tend to write more descriptively. Men's style may be described as a narrative because they focus on presenting ideas and concepts succinctly, using a tight narrative to present their arguments and ideological messages. Meanwhile, female community members have a more descriptive style, as they tend to focus more on depicting specific sequences. They are seen as being more illustrative than reflective.

\section{Conclusion}

Freedom of expression opens new spaces for men and women to be active in literary communities. However, there is a big gap between the presence of men and women in the activities. In both cities, Yogyakarta and Surakarta, men still dominate the literary sphere, and their occupation of this social space has a significant effect on its construction. However, related to social capital, the fact that Yogyakarta is a bigger city having bigger number of universities creates a more possibility to develop their literary communities. They have more opportunities to create social spaces as arenas of contestation for people to express their community identity. This bigger space is also benefited by women. Surakarta, although it is also a cultural city, has less number of universities. The development of literary communities is not as intensive as in Yogyakarta. Their contestation in social spaces is less visible although it cannot be said that they are less important in the development of literature. Women also are less visible in Surakarta than in Yogyakarta.

From the composition of social capital, the cultural and symbolic capitals play an important role in positioning the gender relation. As a cultural capital, the change of political situation enables people to have more spaces to express their ideas and take part in the organizations and cultural communities. In the context of gender, it is similar between Yogyakarta and Surakarta where women can involve in the literary communities. However, from a gender relations perspective, men are dominant in the narration of their literary communities and most active in determining their communities' trajectories and visions. Conversely, women have minimal space, as the social structure requires them to leave their communities for domestic reasons. The burden in the domestic sphere creates only a limited space for women to express their narration. However, despite this limited space, they are capable of narrating themselves as subjects, albeit with themes that do not entirely subjectify women, such as their isolation within the literary realm.

From the trajectory point of view, the bigger space in Yogyakarta enables women to be more active in presenting their perspectives than in Surakarta. There is a strong correlation between women's social space in public space and their presence in the literary community space. The limited space of women in the community cannot be separated from their small space in daily life. This situation creates women limited space in their production space in the literary communities. This pattern is similar between the case of literary space in Yogyakarta and Surakarta. The access of women to be present in public space in daily life is very important to motivate them to be active in literary communities.

The trajectory of men and women is also different. Male members, with an ample space provided in the public sphere, enable them to be subjected to direct the trajectory in their communities. Female members, on the contrary, follow only the trajectory of male members. This is similar between women in Yogyakarta and Surakarta. They become only male supporters and still try to build their format of productivity. It does not mean that they are not able to build their trajectory. However, the situation where being active in the literary communities is not the priority for women places them in the periphery in the construction of the communities' trajectory.

In terms of literary works, men tend to explore not only their own identity but also women's identity, for instance, narrating about women's life, body, and sexuality. They cross the border of their own sexual identity. However, women only narrate their own identity. The fact that the power relation between men and women in the communities is still unequal creates this imbalance in the literary expression. The male gaze is still becoming the way how the communities are founded.

\section{References}

Agustina, E., \& Udasmoro, W. (2018). Women and Pleasure in Guillaume Apollinaire's Calligram Collection Poèmes à Lou. Jurnal Kata, 17, 26--32.

Anwar, S. (2013). Persada Studi Klub: Disposisi dan Pencapaiannya dalam Arena Sastra Nasional. Universitas Gadjah Mada.

Bourdieu, P. (1977). Outline of Theory of Practice. Cambridge: Cambridge University Press.

Bourdieu, P. (1984). Distinction: A Social Critique of the Judgement of Taste. Cambridge Massachusetts: Harvard University Press.

Bourdieu, P. (1990). The Logic of Practice. Stanford: Stanford University Press.

Bourdieu, P. (1991). Language and Symbolic Power. Cambridge: Polity Press.

Brimicombe, A. (2010). GIS Environmental Modelling and Engineering (2nd ed.). New York: Taylor and Francis Group.

Claval, P. (1984). The Concept of Social Space and the Nature of Geography in New Zealand. Geographer, 40 (2), 105-109 .

Condominas, G. (1980). Essai sur l'evolution des systemes politique thai's. In L'Espace Social A Propos de l'Asie du Sud-Est (pp. 256--316). Paris: Flammarion.

Crenshaw, K. W. (1994). Mapping the Margins: Intersectionality, Identity Politics, and Violence Against 
Women of Color. In R. M. Martha Albertson Fineman (Ed.), The Public Nature of Private Violence (pp. 93--98). New York: Routledge.

Friedan, B. (1963). The Feminine Mystique. New York: W.W. Norton \& Company Inc.

Giddens, A. (1991). Modernity and Self-Identity: Self and Society in the Late Modern Era. California: Stanford University Press.

Indrianto, F. N. (2016). Strategi Pemerolehan Modal Simbolik Denny JA dalam Arena Sastra Indonesia: Pendekatan Sosiologi Sastra Pierre Bourdieu. Universitas Gadjah Mada.

Lefebvre, H. (1974). La Production de l'Espace. L'Homme et La Societe, 31--32, 15--32.

Maguire, D. (2008). GIS and Science. In GIS Best Practices (pp. 1--8). New York: ESRI.

Mahmud, A. (2015). Strategi dan Disposisi Abdurahman Faiz dalam Arena Sastra Indonesia Pasca-Orde Baru. Analisis Produksi Kultural Pierre Bourdieu. Universitas Gadjah Mada.

Mohanty, C. T. (2003). Under the Western Eyes: Feminist Scholarship and Colonial Discourses. In Feminism without Borders: Decolonizing Theory, Practicing Solidarity. Duke University Press.

Mulvey, L. (1975). Visual Pleasure and the Narrative Cinema. Madison.

Munk, M. (2003). The Trace of the Social Space: The Theory of Strategies of Reconversions. Copenhagen: Danish National Institute of Social Research.

Nugraha, L. S. (2015). Emha Ainun Nadjib dalam Arena Sastra dan Arena Sosial. Universitas Gadjah Mada.

O'Rourke, K. (2002). Reformasi: The Struggle for Power in Post Soeharto Indonesia. New South Wales: Allen \& Unwin.

Rizki, A. T. (2014). Pergeseran Kekuasaan Negara dan Relasi Antarsubjek dalam Cerpen Orde Baru dan Reformasi. Jurnal Poetika, 2(2), 127--136.
Sahid, N. (2012). Dramaturgi Teater Gandrik Yogyakarta dalam Lakon Orde Tabung dan Departemen Borok. Universitas Gadjah Mada.

Salam, A. (2013). Sastra Yogya dalam Teori Bourdieu (No. 9 June). Yogyakarta.

Salam, A. (2014). Strategi dan Legitimasi Komunitas Sastra di Yogyakarta: Kajian Sosiologi Sastra Pierre Bourdieu. Yogyakarta.

Shimazu, T. (1995). (1995). Durkheim's Theory of Social Space. Annals of the Association of Economic Geographers, 41(1), 20--36.

Staeheli, L. A., \& P.M., M. (2000). Spaces for Feminism in Geography. ANNALS AAPSS 571, 137--150.

Tuchman, G. (1978). Introduction :The Symbolic Annihilation of Women by the Mass Media. In J. Tuchman, G, Daniels, A.K. \& Benet (Ed.), Hearth and Home: Image of Women in the Mass Media (pp. 3--38). New York: Oxford University Press.

Udasmoro, W. (2014). Konstruksi Identitas Remaja dalam Karya Sastra. Yogyakarta: French Literature Program, Universitas Gadjah Mada.

Udasmoro, W. (2017). Dari Doing ke Undoing Gender. Yogyakarta: Gadjah Mada University Press.

Udasmoro, W. (2018). The Language Construction of Muslims as the Other in French Contemporary Discourses. Indonesian Journal of Islam and Muslim Societies, 7 (1, June), 77--99.

Valenta, M. (2010). Refugees' Social Trajectories and Trajectories of the Self [47 paragraphs]. Forum Qualitative Sozialforschung / Forum: Qualitative Social Research, 11 (2).

Yuwono, J., U.N. Winardi, \& Saktimulya, S. R. (2017). Pemetaan PartisipatifPotensi Budaya Gunungkidul untuk Penguatan dan Pengembangan Identitas dan Integritas Budaya Lokal (Tahap I: Kecamatan Wonosari). 